\title{
Fabrication and Characterization of Quinary High Entropy-Ultra-High Temperature Diborides
}

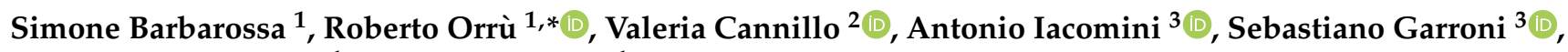 \\ Massimiliano Murgia ${ }^{1}$ and Giacomo Cao ${ }^{1}$
}

1 Dipartimento di Ingegneria Meccanica, Chimica e dei Materiali, Università degli Studi di Cagliari, via Marengo 2, 09123 Cagliari, Italy; barbarossa.simone12@gmail.com (S.B.); massi.murgia93@gmail.com (M.M.); giacomo.cao@dimcm.unica.it (G.C.)

2 Dipartimento di Ingegneria "Enzo Ferrari", Università di Modena e Reggio Emilia, via P. Vivarelli 10, 41125 Modena, Italy; valeria.cannillo@unimore.it

3 Dipartimento di Chimica e Farmacia, Università degli Studi di Sassari, via Vienna 2, 07100 Sassari, Italy; aiacomini@uniss.it (A.I.); sgarroni@uniss.it (S.G.)

* Correspondence: roberto.orru@dimcm.unica.it; Tel.: +39-070-6755076

\section{check for} updates

Citation: Barbarossa, S.; Orrù, R.; Cannillo, V.; Iacomini, A.; Garroni, S.; Murgia, M.; Cao, G. Fabrication and Characterization of Quinary High Entropy-Ultra-High Temperature Diborides. Ceramics 2021, 4, 108-120. https: / / doi.org/10.3390/ ceramics4020010

Academic Editors: Manuel Belmonte, Claude Estournes, Angel L. Ortiz, Koji Morita and Gilbert Fantozzi

Received: 22 February 2021

Accepted: 19 March 2021

Published: 25 March 2021

Publisher's Note: MDPI stays neutral with regard to jurisdictional claims in published maps and institutional affiliations.

Copyright: (c) 2021 by the authors. Licensee MDPI, Basel, Switzerland. This article is an open access article distributed under the terms and conditions of the Creative Commons Attribution (CC BY) license (https:// creativecommons.org/licenses/by/ $4.0 /)$.

\begin{abstract}
Due to their inherent chemical complexity and their refractory nature, the obtainment of highly dense and single-phase high entropy (HE) diborides represents a very hard target to achieve. In this framework, homogeneous $\left(\mathrm{Hf}_{0.2} \mathrm{Nb}_{0.2} \mathrm{Ta}_{0.2} \mathrm{Mo}_{0.2} \mathrm{Ti}_{0.2}\right) \mathrm{B}_{2},\left(\mathrm{Hf}_{0.2} \mathrm{Zr}_{0.2} \mathrm{Ta}_{0.2} \mathrm{Mo}_{0.2} \mathrm{Ti}_{0.2}\right) \mathrm{B}_{2}$, and $\left(\mathrm{Hf}_{0.2} \mathrm{Zr}_{0.2} \mathrm{Nb}_{0.2} \mathrm{Mo}_{0.2} \mathrm{Ti}_{0.2}\right) \mathrm{B}_{2}$ ceramics with high relative densities $(97.4,96.5$, and 98.2\%, respectively) were successfully produced by spark plasma sintering (SPS) using powders prepared by self-propagating high-temperature synthesis (SHS). Although the latter technique did not lead to the complete conversion of initial precursors into the prescribed HE phases, such a goal was fully reached after SPS $\left(1950^{\circ} \mathrm{C} / 20 \mathrm{~min} / 20 \mathrm{MPa}\right)$. The three HE products showed similar and, in some cases, even better mechanical properties compared to ceramics with the same nominal composition attained using alternative processing methods. Superior Vickers hardness and elastic modulus values were found for the $\left(\mathrm{Hf}_{0.2} \mathrm{Nb}_{0.2} \mathrm{Ta}_{0.2} \mathrm{Mo}_{0.2} \mathrm{Ti}_{0.2}\right) \mathrm{B}_{2}$ and the $\left(\mathrm{Hf}_{0.2} \mathrm{Zr}_{0.2} \mathrm{Ta}_{0.2} \mathrm{Mo}_{0.2} \mathrm{Ti}_{0.2}\right) \mathrm{B}_{2}$ systems, i.e., 28.1 GPa/538.5 GPa and 28.08 GPa/498.1 GPa, respectively, in spite of the correspondingly higher residual porosities (1.2 and $2.2 \mathrm{vol} \%$, respectively). In contrast, the third ceramic, not containing tantalum, displayed lower values of these two properties (25.1 GPa/404.5 GPa). However, the corresponding fracture toughness $\left(8.84 \mathrm{MPa}^{1 / 2}\right)$ was relatively higher. This fact can be likely ascribed to the smaller residual porosity $(0.3 \mathrm{vol} . \%)$ of the sintered material.
\end{abstract}

Keywords: high entropy metal borides; spark plasma sintering; self-propagating high-temperature synthesis; mechanical properties

\section{Introduction}

As a novel category of the wider family of ultra high temperature ceramics (UHTCs), high entropy (HE) transition metal diborides, often referred to as HEBs, have immediately gained a significant interest for their potential applications as structural materials in extreme environments [1]. HEBs basically originate from the combination of five or four individual diborides $\left(\mathrm{ZrB}_{2}, \mathrm{HfB}_{2}\right.$, etc.) in near-equimolar ratio to give quinary or quaternary, respectively, crystalline solid solutions with maximum configurational entropy [2]. Since the pioneering work by Gild and coworkers [1], various studies have been carried out for the fabrication of these systems in bulk form and the characterization of the resulting products [1,3-16]. The large majority of these investigations take advantage of the use of the spark plasma sintering (SPS) technology, which is able to guarantee relatively milder conditions, particularly shorter processing times, compared to conventional hot-pressing methods to provide dense materials [17]. Nonetheless, when considering HEB ceramics, the additional hard target to achieve other than the high consolidation level is represented 
by the obtainment of such complex materials as single-phase. Table 1 summarizes the processing methods and the related conditions adopted thus far in the literature for the fabrication of various dense quinary HEBs by SPS. Basically, three approaches are considered: (1) simultaneous synthesis and densification of the ceramic from untreated [13] or ball milled [11] elemental precursors; (2) SPS of pretreated individual borides [1,3,12]; (3) synthesis of HEB-based powders and their subsequent consolidation [4-10,13-16].

Table 1. Quinary high entropy metal borides (HEBs) obtained in bulk form by spark plasma sintering (SPS) with details on powder pretreatments and corresponding experimental conditions adopted $\left(\mathrm{T}_{\mathrm{D}}=\right.$ dwell temperature, $\mathrm{P}=$ mechanical pressure, $t_{H}=$ total heating time to reach $\mathrm{T}_{\mathrm{D}} ; \mathrm{t}_{\mathrm{D}}=\mathrm{dwell}$ time at $\mathrm{T}_{\mathrm{D}}, \mathrm{P}_{\mathrm{w}, \max }=$ maximum electric power, $\mathrm{CR}=$ charge ratio; HEBM: high energy ball milling; BR: borothermal reduction; BCR: boro-carbothermal reduction; SHS: self-propagating high-temperature synthesis; RSPS: reactive SPS; FSPS: flash SPS; n.r. not reported.

\begin{tabular}{|c|c|c|c|c|}
\hline Systems & Raw Powders & $\begin{array}{c}\text { Method/Conditions for } \\
\text { Powders } \\
\text { Synthesis/Activation }\end{array}$ & $\begin{array}{l}\text { SPS Conditions } \\
\qquad\left(\mathrm{T}_{\mathrm{D}} / \mathrm{t}_{\mathrm{H}} / \mathrm{t}_{\mathrm{D}} / \mathrm{P}\right)\end{array}$ & References \\
\hline $\begin{array}{c}\left(\mathrm{Hf}_{0.2} \mathrm{Zr}_{0.2} \mathrm{Ta}_{0.2} \mathrm{Nb}_{0.2} \mathrm{Ti}_{0.2}\right) \mathrm{B}_{2} \\
\left(\mathrm{Hf}_{0.2} \mathrm{Zr}_{0.2} \mathrm{Ta}_{0.2} \mathrm{Mo}_{0.2} \mathrm{Ti}_{0.2}\right) \mathrm{B}_{2} \\
\left.\left(\mathrm{Hf}_{0.2} \mathrm{Zr}_{0.2} \mathrm{Mo}_{0.2} \mathrm{Nb}_{0.2} \mathrm{Ti}_{0.2}\right) \mathrm{B}_{2}\right) \\
\left(\mathrm{Hf}_{0.2} \mathrm{Mo}_{0.2} \mathrm{Ta}_{0.2} \mathrm{Nb}_{0.2} \mathrm{Ti}_{0.2}\right) \mathrm{B}_{2} \\
\left(\mathrm{Mo}_{0.2} \mathrm{Zr}_{0.2} \mathrm{Ta}_{0.2} \mathrm{Nb}_{0.2} \mathrm{Ti}_{0.2}\right) \mathrm{B}_{2} \\
\left(\mathrm{Hf}_{0.2} \mathrm{Zr}_{0.2} \mathrm{~W}_{0.2} \mathrm{Mo}_{0.2} \mathrm{Ti}_{0.2}\right) \mathrm{B}_{2} \\
\left(\mathrm{Hf}_{0.2} \mathrm{Zr}_{0.2} \mathrm{Ta}_{0.2} \mathrm{Cr}_{0.2} \mathrm{Ti}_{0.2}\right) \mathrm{B}_{2}\end{array}$ & Individual metal borides & $\operatorname{HEBM}(\mathrm{CR}=$ n.r. $/ 6$ h) & $\begin{array}{c}\left(2000{ }^{\circ} \mathrm{C} / \sim 20 \mathrm{~min} /\right. \\
5 \mathrm{~min} / 30 \mathrm{MPa})\end{array}$ & {$[1]$} \\
\hline$\left(\mathrm{Hf}_{0.2} \mathrm{Mo}_{0.2} \mathrm{Ta}_{0.2} \mathrm{Nb}_{0.2} \mathrm{Ti}_{0.2}\right) \mathrm{B}_{2}$ & $\begin{array}{c}\text { Metal powders, } \\
\text { B }\end{array}$ & $\begin{array}{l}\text { SHS (few secs })+ \text { HEBM } \\
\quad(C R=2 / 20-60 \mathrm{~min})\end{array}$ & $\begin{array}{l}\left(1950{ }^{\circ} \mathrm{C} / 10 \mathrm{~min} /\right. \\
20 \mathrm{~min} / 20 \mathrm{MPa})\end{array}$ & {$[5,13]$} \\
\hline $\begin{array}{l}\left(\mathrm{Hf}_{0.2} \mathrm{Zr}_{0.2} \mathrm{Ta}_{0.2} \mathrm{Cr}_{0.2} \mathrm{Ti}_{0.2}\right) \mathrm{B}_{2} \\
\left(\mathrm{Hf}_{0.2} \mathrm{Mo}_{0.2} \mathrm{Zr}_{0.2} \mathrm{Nb}_{0.2} \mathrm{Ti}_{0.2}\right) \mathrm{B}_{2} \\
\left(\mathrm{Hf}_{0.2} \mathrm{Mo}_{0.2} \mathrm{Ta}_{0.2} \mathrm{Nb}_{0.2} \mathrm{Ti}_{0.2}\right) \mathrm{B}_{2}\end{array}$ & $\begin{array}{l}\text { Metal oxides, } \\
\text { B }\end{array}$ & $\mathrm{BR}\left(1600{ }^{\circ} \mathrm{C} / 60 \mathrm{~min}\right)$ & $\begin{array}{c}\left(2000{ }^{\circ} \mathrm{C} / \sim 13 \mathrm{~min} /\right. \\
10 \mathrm{~min} / 30 \mathrm{MPa})\end{array}$ & {$[6]$} \\
\hline $\begin{array}{l}\left(\mathrm{Hf}_{0.2} \mathrm{Zr}_{0.2} \mathrm{Ta}_{0.2} \mathrm{Nb}_{0.2} \mathrm{Ti}_{0.2}\right) \mathrm{B}_{2} \\
\left(\mathrm{Hf}_{0.2} \mathrm{Zr}_{0.2} \mathrm{Mo}_{0.2} \mathrm{Nb}_{0.2} \mathrm{Ti}_{0.2}\right) \mathrm{B}_{2} \\
\left(\mathrm{Hf}_{0.2} \mathrm{Mo}_{0.2} \mathrm{Ta}_{0.2} \mathrm{Nb}_{0.2} \mathrm{Ti}_{0.2}\right) \mathrm{B}_{2}\end{array}$ & $\begin{array}{l}\text { Metal oxides, } \\
\mathrm{B}_{4} \mathrm{C} \text {, graphite }\end{array}$ & $\mathrm{BCR}\left(1600{ }^{\circ} \mathrm{C} / 60 \mathrm{~min}\right)$ & $\begin{array}{c}\left(2000{ }^{\circ} \mathrm{C} / \sim 13 \mathrm{~min} /\right. \\
10 \mathrm{~min} / 30 \mathrm{MPa})\end{array}$ & [7] \\
\hline$\left(\mathrm{Hf}_{0.2} \mathrm{Zr}_{0.2} \mathrm{Ta}_{0.2} \mathrm{Nb}_{0.2} \mathrm{Ti}_{0.2}\right) \mathrm{B}_{2}$ & $\begin{array}{l}\text { Individual metal borides, } \\
\text { graphite }\end{array}$ & $\begin{array}{c}\text { Pre-sintering by SPS } \\
\left(1600{ }^{\circ} \mathrm{C} / 5 \mathrm{~min} / 30 \mathrm{MPa}\right)\end{array}$ & $\begin{array}{c}\text { FSPS }\left(30 \% \mathrm{P}_{\mathrm{w}, \max } / 120 \mathrm{~s}+\right. \\
50 \% \mathrm{P}_{\mathrm{w}, \max } / 30 \mathrm{~s}+ \\
\left.100 \% \mathrm{P}_{\mathrm{w}, \max } / 90 \mathrm{~s}\right)\end{array}$ & {$[3]$} \\
\hline$\left(\mathrm{Hf}_{0.2} \mathrm{Zr}_{0.2} \mathrm{Ta}_{0.2} \mathrm{Nb}_{0.2} \mathrm{Ti}_{0.2}\right) \mathrm{B}_{2}$ & $\begin{array}{l}\text { Metal oxides, } \\
\mathrm{B}_{4} \mathrm{C} \text {, graphite }\end{array}$ & $\begin{array}{c}\text { BCR by SPS } \\
\left(1700^{\circ} \mathrm{C} / 10 \mathrm{~min}\right)\end{array}$ & $\begin{array}{c}\left(2000{ }^{\circ} \mathrm{C} / \sim 20 \mathrm{~min} /\right. \\
5 \mathrm{~min} / 50 \mathrm{MPa})\end{array}$ & {$[4]$} \\
\hline$\left(\mathrm{Hf}_{0.2} \mathrm{Mo}_{0.2} \mathrm{Ta}_{0.2} \mathrm{Nb}_{0.2} \mathrm{Ti}_{0.2}\right) \mathrm{B}_{2}$ & $\begin{array}{c}\text { Metal powders, } \\
\text { B }\end{array}$ & None & $\begin{array}{l}\text { RSPS }\left(1950{ }^{\circ} \mathrm{C} / 10 \mathrm{~min} /\right. \\
20 \mathrm{~min} / 20-70 \mathrm{MPa})\end{array}$ & {$[13]$} \\
\hline $\begin{array}{c}\left(\mathrm{Hf}_{0.2} \mathrm{Mo}_{0.2} \mathrm{Ta}_{0.2} \mathrm{Nb}_{0.2} \mathrm{Ti}_{0.2}\right) \mathrm{B}_{2} \\
\left(\mathrm{Hf}_{0.2} \mathrm{Zr}_{0.2} \mathrm{Ta}_{0.2} \mathrm{Mo}_{0.2} \mathrm{Ti}_{0.2}\right) \mathrm{B}_{2}\end{array}$ & $\begin{array}{l}\text { Metal powders, } \\
\text { B, graphite }\end{array}$ & $\begin{array}{l}\text { SHS (few seconds) + HEBM } \\
(\mathrm{CR}=2,60 \mathrm{~min})\end{array}$ & $\begin{array}{l}\left(1950{ }^{\circ} \mathrm{C} / 10 \mathrm{~min} /\right. \\
20 \mathrm{~min} / 20 \mathrm{MPa}) \\
\end{array}$ & [8] \\
\hline $\begin{array}{l}\left(\mathrm{Hf}_{0.2} \mathrm{Zr}_{0.2} \mathrm{Ta}_{0.2} \mathrm{Nb}_{0.2} \mathrm{Ti}_{0.2}\right) \mathrm{B}_{2} \\
\left(\mathrm{Hf}_{0.2} \mathrm{Zr}_{0.2} \mathrm{Mo}_{0.2} \mathrm{~W}_{0.2} \mathrm{Ti}_{0.2}\right) \mathrm{B}_{2}\end{array}$ & $\begin{array}{c}\text { Metal oxides, } \\
\text { B }\end{array}$ & $\mathrm{BR}\left(1600{ }^{\circ} \mathrm{C} / 60 \mathrm{~min}\right)$ & $\begin{array}{c}\left(2000{ }^{\circ} \mathrm{C} / \text { n.r. } /\right. \\
10 \mathrm{~min} / 30 \mathrm{MPa})\end{array}$ & {$[14]$} \\
\hline $\begin{array}{c}\left(\mathrm{Hf}_{0.2} \mathrm{Zr}_{0.2} \mathrm{Ta}_{0.2} \mathrm{Nb}_{0.2} \mathrm{Ti}_{0.2}\right) \mathrm{B}_{2} \\
\left(\mathrm{Hf}_{0.2} \mathrm{Zr}_{0.2} \mathrm{Ta}_{0.2} \mathrm{Mo}_{0.2} \mathrm{Ti}_{0.2}\right) \mathrm{B}_{2} \\
\left(\mathrm{Hf}_{0.2} \mathrm{Zr}_{0.2} \mathrm{~W}_{0.2} \mathrm{Mo}_{0.2} \mathrm{Ti}_{0.2}\right) \mathrm{B}_{2} \\
\left(\mathrm{Hf}_{0.2} \mathrm{Zr}_{0.2} \mathrm{Ta}_{0.2} \mathrm{Cr}_{0.2} \mathrm{Ti}_{0.2}\right) \mathrm{B}_{2}\end{array}$ & $\begin{array}{l}\text { Metal oxides, } \\
\qquad \mathrm{B}_{4} \mathrm{C}, \mathrm{C}\end{array}$ & $\mathrm{BCR}\left(1550{ }^{\circ} \mathrm{C} / 90 \mathrm{~min}\right)$ & $\begin{array}{c}\left(2000{ }^{\circ} \mathrm{C} / \sim 20 \mathrm{~min} /\right. \\
30 \mathrm{~min} / 80 \mathrm{MPa})\end{array}$ & {$[10]$} \\
\hline$\left(\mathrm{Hf}_{0.2} \mathrm{Zr}_{0.2} \mathrm{Ta}_{0.2} \mathrm{Nb}_{0.2} \mathrm{Ti}_{0.2}\right) \mathrm{B}_{2}$ & $\begin{array}{l}\text { Metal oxides, } \\
\quad \mathrm{B}_{4} \mathrm{C}, \mathrm{C}\end{array}$ & $\mathrm{BCR}\left(1650^{\circ} \mathrm{C} / 3.5 \mathrm{~h}\right)$ & $\begin{array}{c}\left(2000-2200{ }^{\circ} \mathrm{C} / \sim 23 \mathrm{~min} /\right. \\
10 \mathrm{~min} / 50 \mathrm{MPa})\end{array}$ & [9] \\
\hline $\begin{array}{c}\quad\left(\mathrm{Hf}_{0.2} \mathrm{Zr}_{0.2} \mathrm{Ta}_{0.2} \mathrm{Nb}_{0.2} \mathrm{Ti}_{0.2}\right) \mathrm{B}_{2} \\
\left(\mathrm{Hf}_{0.2} \mathrm{Zr}_{0.2375} \mathrm{Ta}_{0.2375} \mathrm{Nb}_{0.05} \mathrm{Ti}_{0.2375}\right) \mathrm{B}_{2}\end{array}$ & $\begin{array}{l}\text { Metal oxides, } \\
\quad \mathrm{B}_{4} \mathrm{C}, \mathrm{C}\end{array}$ & $\operatorname{BCR}\left(1650^{\circ} \mathrm{C} / 3 \mathrm{~h}\right)$ & $\begin{array}{l}\left(2100{ }^{\circ} \mathrm{C} / \sim 23 \mathrm{~min} /\right. \\
10 \mathrm{~min} / 50 \mathrm{MPa})\end{array}$ & {$[15]$} \\
\hline$\left(\mathrm{Hf}_{0.2} \mathrm{Zr}_{0.2} \mathrm{Ta}_{0.2} \mathrm{Cr}_{0.2} \mathrm{Ti}_{0.2}\right) \mathrm{B}_{2}$ & $\begin{array}{l}\text { Metal oxides, } \\
\quad \mathrm{B}_{4} \mathrm{C}, \mathrm{C}\end{array}$ & $\mathrm{BCR}\left(1650^{\circ} \mathrm{C} / 1 \mathrm{~h}\right)$ & $\begin{array}{c}\left(2000{ }^{\circ} \mathrm{C} / \sim 13 \mathrm{~min} /\right. \\
10 \mathrm{~min} / 30 \mathrm{MPa})\end{array}$ & [16] \\
\hline $\begin{array}{c}\left(\mathrm{Hf}_{0.2} \mathrm{Zr}_{0.2} \mathrm{Ta}_{0.2} \mathrm{Nb}_{0.2} \mathrm{Ti}_{0.2}\right) \mathrm{B}_{2} \\
\left(\mathrm{Mo}_{0.2} \mathrm{Zr}_{0.2} \mathrm{Ta}_{0.2} \mathrm{Nb}_{0.2} \mathrm{Ti}_{0.2}\right) \mathrm{B}_{2} \\
\left(\mathrm{Hf}_{0.2} \mathrm{Zr}_{0.2} \mathrm{~W}_{0.2} \mathrm{Mo}_{0.2} \mathrm{Ti}_{0.2}\right) \mathrm{B}_{2} \\
\left(\mathrm{Ti}_{0.2} \mathrm{Ta}_{0.2} \mathrm{Cr}_{0.2} \mathrm{Mo}_{0.2} \mathrm{~W}_{0.2}\right) \mathrm{B}_{2} \\
\left(\mathrm{Zr}_{0.2} \mathrm{Hf}_{0.2} \mathrm{Nb}_{0.2} \mathrm{Ta}_{0.2} \mathrm{~W}_{0.2}\right) \mathrm{B}_{2} \\
\left(\mathrm{Zr}_{0.225} \mathrm{Hf}_{0.225} \mathrm{Ta}_{0.225} \mathrm{Mo}_{0.225} \mathrm{~W}_{0.1}\right) \mathrm{B}_{2}\end{array}$ & $\begin{array}{c}\text { Metal powders, } \\
\text { B }\end{array}$ & $\operatorname{HEBM}(\mathrm{CR}=4,50 \mathrm{~min})$ & $\begin{array}{l}\text { RSPS }\left(2000^{\circ} \mathrm{C} / \sim 2 \mathrm{~h} /\right. \\
\quad 10 \mathrm{~min} / 50 \mathrm{MPa})\end{array}$ & {$[11]$} \\
\hline$\left(\mathrm{Hf}_{0.2} \mathrm{Zr}_{0.2} \mathrm{Ta}_{0.2} \mathrm{Nb}_{0.2} \mathrm{Ti}_{0.2}\right) \mathrm{B}_{2}$ & $\begin{array}{l}\text { Individual metal borides, } \\
\text { graphite }\end{array}$ & $\operatorname{HEBM}(\mathrm{CR}=2.3,100 \mathrm{~min})$ & $\begin{array}{c}\left(2200{ }^{\circ} \mathrm{C} / \sim 3 \mathrm{~h} /\right. \\
10 \mathrm{~min} / 80 \mathrm{MPa})\end{array}$ & [12] \\
\hline
\end{tabular}


As far as the first route is concerned, the one-step reactive SPS (RSPS) process (30 min duration) from simply blended elemental powders provided a multiphase ceramic [4]. More recently, beneficial effects in terms of product homogeneity and densification arose with the activation by high energy ball milling $(\mathrm{HEBM})($ charge ratio $(\mathrm{CR})=4$ ) of starting reactants combined with a multistep SPS process (duration of about $2 \mathrm{~h}$ ) [11]. A mechanical treatment is also used to activate individual boride constituents [1,12]. The main drawback related to HEBM is, depending on milling intensity and duration, the presence of possible oxide impurities or other contaminants from milling tools in the resulting powders [1]. On the other hand, a milder milling treatment might require relatively more severe SPS conditions $\left(2200^{\circ} \mathrm{C} / 3 \mathrm{~h} / 10 \mathrm{~min} / 80 \mathrm{MPa}\right)$ [12] if compared to those adopted in other studies (Table 1). An alternative proposed approach was the flash SPS (FSPS) preceded by a presintering SPS step to activate powder mixture of metal borides [3]. In spite of its undeniable advantage represented by process rapidity, FSPS is a quite difficult process to control. Therefore, as shown in Table 1 , the generally adopted fabrication method typically involves first the preparation of HEB powders and then their densification by SPS. In this framework, the borothermal (BR) and the boro-carbothermal reduction (BCR) of metal oxides were certainly the most utilized synthesis methods $[4-7,10,15,16]$. The resulting powders were usually able to provide highly dense and quite homogeneous materials after SPS. However, these routes present some drawbacks, such as possible presence of unreacted oxides, high temperatures (1600-1700 ${ }^{\circ} \mathrm{C}$ ), and long processing times (including non-isothermal heatingcooling steps). As an alternative method for powder preparation, the self-propagating high-temperature synthesis (SHS) was utilized for the cases of $\left(\mathrm{Hf}_{0.2} \mathrm{Mo}_{0.2} \mathrm{Ta}_{0.2} \mathrm{Nb}_{0.2} \mathrm{Ti}_{0.2}\right) \mathrm{B}_{2}$ and $\left(\mathrm{Hf}_{0.2} \mathrm{Zr}_{0.2} \mathrm{Ta}_{0.2} \mathrm{Mo}_{0.2} \mathrm{Ti}_{0.2}\right) \mathrm{B}_{2}[5,8]$. Although the corresponding SHS products did not consist exclusively of the desired HEB phases, such a goal was successfully achieved with the subsequent SPS stage. SHS has the main advantage to take place very shortly, within a few seconds, and to be convenient from the energetic viewpoint due to the capability of the synthesis process to self-propagate upon local ignition. As a constraint, suitable precursors have to be identified to provide the due exothermicity required to guarantee the SHS character to the reacting system. In this regard, the reactions of formation of transition metal diborides from their elements typically satisfy the latter requirement. Another advantage associated with the use of the SHS technique is the fact that the related powders, for instance, zirconium diboride, are observed to display improved sinterability with respect to those prepared using alternative techniques (furnace, solution methods, etc.) $[18,19]$. The higher defect concentration generated in the SHS powders by the extreme heating and cooling rate conditions established during the propagation of the reaction front (order of $10^{5}$ and $10^{3} \mathrm{~K} / \mathrm{min}$, respectively) provided a possible explanation for such a finding [18]. Accordingly, the combination of the SHS and SPS methods was adopted for the fabrication of a wide variety of UHTCs, including monophasic transition metal borides [5,8,20-25].

Along these lines, a novel HEB system, namely $\left(\mathrm{Hf}_{0.2} \mathrm{Zr}_{0.2} \mathrm{Nb}_{0.2} \mathrm{Mo}_{0.2} \mathrm{Ti}_{0.2}\right) \mathrm{B}_{2}$, was studied for the first time in the present work according to the latter processing route. Both the SHS powders and the SPS bulk product were characterized in detail from the compositional and the structural points of view. The results were compared with those relative to $\left(\mathrm{Hf}_{0.2} \mathrm{Mo}_{0.2} \mathrm{Ta}_{0.2} \mathrm{Nb}_{0.2} \mathrm{Ti}_{0.2}\right) \mathrm{B}_{2}$ and $\left(\mathrm{Hf}_{0.2} \mathrm{Zr}_{0.2} \mathrm{Ta}_{0.2} \mathrm{Mo}_{0.2} \mathrm{Ti}_{0.2}\right) \mathrm{B}_{2}$ ceramics processed under the same conditions.

Another crucial aspect concerning HEBs is represented by the lack of literature data relative to their mechanical properties. Indeed, although preliminary measurements evidenced generally superior hardness as compared to individual binary constituents [1], little information is available on additional mechanical properties. On the other hand, the latter ones are very important to validate this emerging class of ceramics and finally identify one or more promising HEB systems for further focus. To this aim, hardness, elastic modulus, and fracture toughness properties of the optimized dense $\left(\mathrm{Hf}_{0.2} \mathrm{Nb}_{0.2} \mathrm{Ta}_{0.2} \mathrm{Mo}_{0.2} \mathrm{Ti}_{0.2}\right) \mathrm{B}_{2}$, $\left(\mathrm{Hf}_{0.2} \mathrm{Zr}_{0.2} \mathrm{Ta}_{0.2} \mathrm{Mo}_{0.2} \mathrm{Ti}_{0.2}\right) \mathrm{B}_{2}$, and $\left(\mathrm{Hf}_{0.2} \mathrm{Zr}_{0.2} \mathrm{Nb}_{0.2} \mathrm{Mo}_{0.2} \mathrm{Ti}_{0.2}\right) \mathrm{B}_{2}$ products obtained by SHS- 
SPS were measured for the first time in this work. A comparison with literature data, when available, was also carried out.

\section{Materials and Methods}

\subsection{Processing of HEBs}

The preparation of $\left(\mathrm{Hf}_{0.2} \mathrm{Nb}_{0.2} \mathrm{Ta}_{0.2} \mathrm{Mo}_{0.2} \mathrm{Ti}_{0.2}\right) \mathrm{B}_{2},\left(\mathrm{Hf}_{0.2} \mathrm{Zr}_{0.2} \mathrm{Ta}_{0.2} \mathrm{Mo}_{0.2} \mathrm{Ti}_{0.2}\right) \mathrm{B}_{2}$, and $\left(\mathrm{Hf}_{0.2} \mathrm{Zr}_{0.2} \mathrm{Nb}_{0.2} \mathrm{Mo}_{0.2} \mathrm{Ti}_{0.2}\right) \mathrm{B}_{2}$ products, hereto after indicated as HEB_a, HEB_b, and HEB_c, respectively, was carried out starting from Hf (Alfa Aesar, cod. 00337, particle size $<44 \mu \mathrm{m}$, 99.6\% purity), Mo (Aldrich, cod 266892, particle size < $149 \mu \mathrm{m}, 99 \%$ purity), Ta (Alfa Aesar, cod 00337, particle size < $44 \mu \mathrm{m}, 99.9 \%$ purity), Nb (Alfa Aesar, cod 010275, particle size < $44 \mu \mathrm{m}, 99.8 \%$ purity), Ti (Aldrich, cod 268496, particle size $<149 \mu \mathrm{m}, 99.7 \mathrm{pu}-$ rity), Zr (Alfa Aesar, cod 00418, particle size < $44 \mu \mathrm{m},>98.5 \%$ purity), and B (Aldrich, cod 15580, amorphous, 99\% purity) reactants. Metals were combined in stoichiometric proportions, whereas an excess of boron (B to metal ratio of 2.2:1) was used to compensate the partial loss of this element during SHS, as explained elsewhere [5,8]. Powders were first mixed for $20 \mathrm{~min}$ in a SPEX 8000 (SPEX CertiPrep, USA) mill using plastic vials and alumina balls, then cold-pressed to provide cylindrical pellets, which were finally reacted in argon environment by SHS. Details on the experimental apparatus and the procedure are reported in a previous work [26]. The obtained porous product was ball milled for $60 \mathrm{~min}$ (ball-to-powder or charge ratio, $\mathrm{CR}$, equal to two) using the milling device mentioned above and stainless-steel tools. No detectable contamination from milling media was found under such conditions. To improve product purity and densification, about $1 \mathrm{wt}$ \% graphite (Aldrich, cod 282863, particle size 1-2 $\mu \mathrm{m}$ ) was added to the SHS product before being mechanically treated. Such a specific amount of this additive was recently shown to be the optimal one to reduce oxides content and maximize powder consolidation while avoiding the presence of residual graphite in sintered products [8].

SHS powders were loaded in a die (AT101 graphite, ATAL Srl, Italy) of $30 \mathrm{~mm}$ external diameter, $15 \mathrm{~mm}$ inner diameter, and $30 \mathrm{~mm}$ height to produce bulk samples of about $14.7 \mathrm{~mm}$ diameter and $3 \mathrm{~mm}$ thickness. Sintering experiments were conducted in vacuum using SPS equipment (515S model, Fuji Electronic Industrial Co., Ltd., Kanagawa, Japan) under the following conditions: dwell temperature $\left(\mathrm{T}_{\mathrm{D}}\right)$, heating rate, dwell time $\left(\mathrm{t}_{\mathrm{D}}\right)$, and mechanical pressure $(\mathrm{P})$ of $1950{ }^{\circ} \mathrm{C}, 200{ }^{\circ} \mathrm{C} / \mathrm{min}, 20 \mathrm{~min}$, and $20 \mathrm{MPa}$, respectively. The temperature was measured using an infrared pyrometer (CHINO, mod. IR-AHS2, Japan) focused on the die surface. Heat losses by radiation were minimized by covering the die with a layer of graphite felt. For the sake of reproducibility, each experiment was repeated at least twice. The resulting sintered samples were ground to remove residual graphite and finally polished for their characterization.

\subsection{Characterization of HEBs}

Phase composition of SHS and SPS products was determined by X-ray diffraction (XRD) analysis (Philips PW 1830, Netherlands) using $\mathrm{Cu} \mathrm{K} \alpha$ radiation over a range of scattering angles $2 \vartheta$ from $20^{\circ}$ to $130^{\circ}$ in steps of $0.05^{\circ}$ with $15 \mathrm{~s}$ acquisition time per angle. XRD patterns were analyzed using the Rietveld method to quantitatively evaluate, using the MAUD (Material Analysis Using Diffraction) program [27], phases amount (wt.\%) and the related structural parameters.

Particle size distribution of ball milled SHS powders was determined by a laser light scattering analyzer (CILAS 1180, Orléans, France).

Densities of polished samples were measured by Archimedes' method, using distilled water as immersing medium. Relative densities were finally calculated using the theoretical values of $8.67,8.52$, and $7.37 \mathrm{~g} / \mathrm{cm}^{3}$ for $\left(\mathrm{Hf}_{0.2} \mathrm{Nb}_{0.2} \mathrm{Ta}_{0.2} \mathrm{Mo}_{0.2} \mathrm{Ti}_{0.2}\right) \mathrm{B}_{2},\left(\mathrm{Hf}_{0.2} \mathrm{Zr}_{0.2} \mathrm{Ta}_{0.2} \mathrm{Mo}_{0.2} \mathrm{Ti}_{0.2}\right) \mathrm{B}_{2}$, and $\left(\mathrm{Hf}_{0.2} \mathrm{Zr}_{0.2} \mathrm{Nb}_{0.2} \mathrm{Mo}_{0.2} \mathrm{Ti}_{0.2}\right) \mathrm{B}_{2}$, respectively. The presence of graphite was accounted for by considering the additive amount initially introduced in the mixture and the density value of $2.26 \mathrm{~g} / \mathrm{cm}^{3}$, as described elsewhere [8]. 
A high-resolution scanning electron microscopy (HR-SEM, mod. S4000, Hitachi, Tokyo, Japan) equipped with an UltraDry EDS (Energy Dispersive Spectroscopy) detector (Thermo Fisher Scientific, Waltham, MA, USA) was used to examine samples microstructure and elemental distributions. To evaluate residual porosity in sintered samples, SEM micrographs were processed using the open source software ImageJ (version 1.54a for Windows, 64 bit, National Institutes of Health, Bethesda, MD, USA) [28].

Mechanical properties of samples were determined by means of the micro-indentation technique using a depth-sensing instrumentation. Measurements were made with the Open-Platform equipment (CSM Instruments, Peseux, Switzerland) with a Vickers indenter tip. Samples were embedded into epoxy resin and then lapped and polished. Such a technique was employed to obtain both Vickers hardness and Young's modulus, setting a load equal to $250 \mathrm{mN}$ with a load/unload rate of $500 \mathrm{mN} / \mathrm{min}$. At least 15 measurements were performed for each sample, and the average values were then calculated. For each indentation, the load-penetration depth curve was automatically acquired. The Young's modulus was calculated from the unloading part of the load-depth curve according to the Oliver and Pharr method [29]. Measurements were then repeated using a load of $500 \mathrm{mN}$ with a load/unload rate of $1 \mathrm{~N} / \mathrm{min}$ to test the reproducibility of the measure and the eventual effect of the applied load.

Finally, fracture toughness was evaluated for the three systems using a load of $1 \mathrm{~N}$ in order to make cracks propagate from the indent tips. Fracture toughness was then calculated based on the crack lengths according to some well know equations available in the literature [30,31], namely:

$$
\begin{array}{ll}
\mathrm{K}_{\mathrm{IC}}=0.0824 \frac{P}{c^{3 / 2}} & \text { (Evans and Charles, E\&C) } \\
\mathrm{K}_{\mathrm{IC}}=0.0515 \frac{P}{c^{3 / 2}} & \text { (Lawn and Fuller, L\&F) } \\
\mathrm{K}_{\mathrm{IC}}=0.079 \frac{P}{a^{3 / 2}} \log \left(\frac{4.5 a}{c}\right) & (\text { Evans and Wilshaw, E\&W) } \\
\mathrm{K}_{\mathrm{IC}}=0.0363\left(\frac{E}{H_{v}}\right)^{\frac{2}{5}} \frac{P}{a^{1.5}}\left(\frac{a}{c}\right)^{1.56} & (\text { Lankford, L) }
\end{array}
$$

where $\mathrm{K}_{\mathrm{IC}}$ is the fracture toughness, $\mathrm{P}$ the load, $\mathrm{c}$ the average crack length measured from the indentation center, a the indentation average half diagonal, $\mathrm{E}$ the elastic modulus, and $\mathrm{H}_{\mathrm{V}}$ the Vickers hardness.

\section{Results and Discussion}

\subsection{Powders Synthesis and Characterization}

The three reacting systems considered in the present work for the synthesis of $\left(\mathrm{Hf}_{0.2} \mathrm{Nb}_{0.2} \mathrm{Ta}_{0.2} \mathrm{Mo}_{0.2} \mathrm{Ti}_{0.2}\right) \mathrm{B}_{2},\left(\mathrm{Hf}_{0.2} \mathrm{Zr}_{0.2} \mathrm{Ta}_{0.2} \mathrm{Mo}_{0.2} \mathrm{Ti}_{0.2}\right) \mathrm{B}_{2}$, and $\left(\mathrm{Hf}_{0.2} \mathrm{Zr}_{0.2} \mathrm{Nb}_{0.2} \mathrm{Mo}_{0.2} \mathrm{Ti}_{0.2}\right) \mathrm{B}_{2}$ from their elements displayed a self-sustaining character upon ignition. The reaction behavior was similar to that observed when considering the combustion synthesis of standard metal diborides from their elements. The very high reaction enthalpies for the formation of these compounds, particularly $\mathrm{HfB}_{2}(335.98 \mathrm{~kJ} / \mathrm{mol}), \mathrm{ZrB}_{2}(322.59 \mathrm{~kJ} / \mathrm{mol})$, and $\mathrm{TiB}_{2}$ $(323.80 \mathrm{~kJ} / \mathrm{mol})$ [32], were clearly responsible for such a finding.

The compositions of HEB_a and HEB_b products obtained by SHS are reported and examined in detail elsewhere [8,13]. On the other hand, the synthesis of $\left(\mathrm{Hf}_{0.2} \mathrm{Zr}_{0.2} \mathrm{Nb}_{0.2} \mathrm{Mo}_{0.2} \mathrm{Ti}_{0.2}\right) \mathrm{B}_{2}$ by SHS was carried out for the first time in this work. The XRD experimental pattern (black rhombohedral) and the best fit (red line) relative to the corresponding SHS product are shown, on a log scale, in Figure 1. A multiphase product was obtained after the synthesis process, which agreed with the results obtained with the other HEB systems previously investigated, i.e., of HEB_a [5] and HEB_b [8]. Rietveld analysis was performed using $\left(\mathrm{Hf}_{0.2} \mathrm{Zr}_{0.2} \mathrm{Nb}_{0.2} \mathrm{Mo}_{0.2} \mathrm{Ti}_{0.2}\right) \mathrm{B}_{2},\left(\mathrm{Hf}_{0.5} \mathrm{Ti}_{0.5}\right) \mathrm{B}_{2},\left(\mathrm{Zr}_{0.5} \mathrm{Ti}_{0.5}\right) \mathrm{B}_{2}$ and $\mathrm{NbB}_{2}$ as a starting model according to Barbarossa et al. [8] for a similar system. The excellent degree of matching of the model with the experimental data was established by the low R-factor $(R w p=6.43 \%)$ achieved for this analysis. Table 2 summarizes structural and microstructural parameters obtained from the Rietveld analysis applied to the pattern reported in Figure 1. 


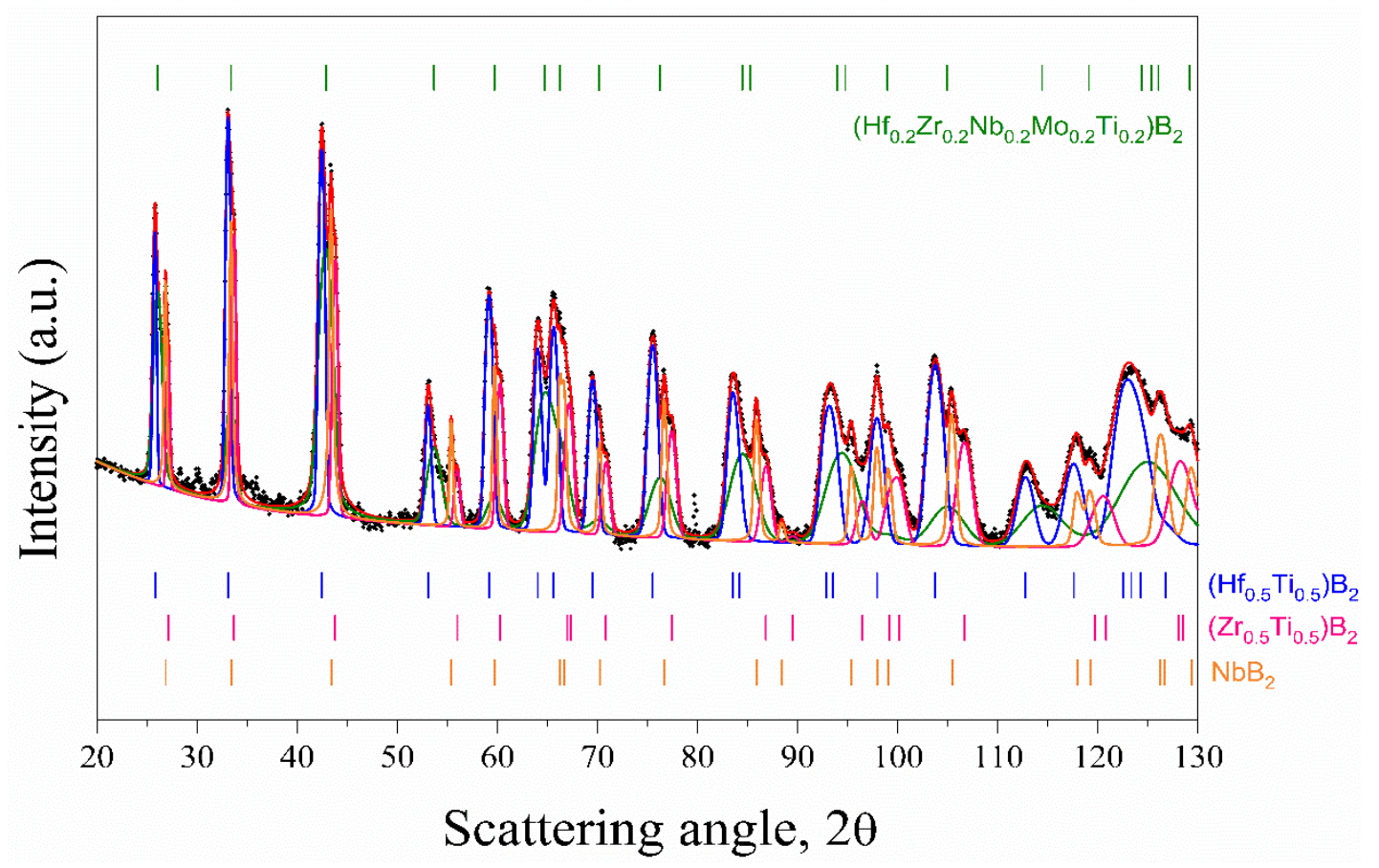

Figure 1. X-ray diffraction (XRD) pattern and related Rietveld refinement of $\left(\mathrm{Hf}_{0.2} \mathrm{Zr}_{0.2} \mathrm{Nb}_{0.2} \mathrm{Mo}_{0.2} \mathrm{Ti}_{0.2}\right) \mathrm{B}_{2}$ product obtained by SHS from elemental powders.

Table 2. Microstructural parameters and relative amounts of each phase estimated by the Rietveld analysis performed on the as-recorded pattern of the HEB_c product obtained by SHS (Figure 1). R.m.s.: Root mean square.

\begin{tabular}{cccccccc}
\hline Phase & Space Group & a $(\AA)$ & $\mathbf{c}(\AA)$ & $\mathbf{V}\left(\AA^{3}\right)$ & Cryst. Size $(\AA)$ & R.m.s. Strain & Phase (\%) \\
\hline$\left(\mathrm{Hf}_{0.2} \mathrm{Zr}_{0.2} \mathrm{Nb}_{0.2} \mathrm{Mo}_{0.2} \mathrm{Ti}_{0.2}\right) \mathrm{B}_{2}$ & $\begin{array}{c}\text { Hexagonal } \\
(\mathrm{P} 6 / \mathrm{mmm})\end{array}$ & 3.0975 & 3.4136 & 28.364 & 507 & $9.6^{*} 10^{-3}$ & 27 \\
$\left(\mathrm{Hf}_{0.5} \mathrm{Ti}_{0.5}\right) \mathrm{B}_{2}$ & $\begin{array}{l}\text { Hexagonal } \\
(\mathrm{P} 6 / \mathrm{mmm})\end{array}$ & 3.1222 & 3.4488 & 29.115 & $>2000$ & $4.0^{*} 10^{-3}$ & 40 \\
$\left(\mathrm{Zr}_{0.5} \mathrm{Ti}_{0.5}\right) \mathrm{B}_{2}$ & $\begin{array}{l}\text { Hexagonal } \\
(\mathrm{P} 6 / \mathrm{mmm})\end{array}$ & 3.0710 & 3.2840 & 26.822 & $>2000$ & $3.8^{*} 10^{-3}$ & 18 \\
$\mathrm{NbB}_{2}$ & $\begin{array}{l}\text { Hexagonal } \\
(\mathrm{P} 6 / \mathrm{mmm})\end{array}$ & 3.0951 & 3.3158 & 27.508 & 1033 & $1.3^{*} 10^{-3}$ & 15 \\
\hline
\end{tabular}

Quantitative analysis revealed that $\left(\mathrm{Hf}_{0.2} \mathrm{Zr}_{0.2} \mathrm{Nb}_{0.2} \mathrm{Mo}_{0.2} \mathrm{Ti}_{0.2}\right) \mathrm{B}_{2}$, $\left(\mathrm{Hf}_{0.5} \mathrm{Ti}_{0.5}\right) \mathrm{B}_{2}$, $\left(\mathrm{Zr}_{0.5} \mathrm{Ti}_{0.5}\right) \mathrm{B}_{2}$ and $\mathrm{NbB}_{2}$ were present in the mixture in percentage by weights of $27 \%$, $40 \%, 18 \%$, and $15 \%$, respectively.

Cell parameters of the high entropy phase in the HEB_c SHS powders were very close to those obtained in the literature for similar ceramics produced by the same route $[5,8]$. For instance, $\mathrm{a}=3.099 \AA$ and $\mathrm{c}=3.390 \AA$ were obtained for $\left(\mathrm{Hf}_{0.2} \mathrm{Zr}_{0.2} \mathrm{Ta}_{0.2} \mathrm{Mo}_{0.2} \mathrm{Ti}_{0.2}\right) \mathrm{B}_{2}$ when considering the HEB_b SHS product [8]. In addition, $\mathrm{NbB}_{2}$ cell parameters found in this work were in good agreement with the literature $(\mathrm{a}=3.086 \AA$; $\mathrm{c}=3.306 \AA)$ [33], while $\left(\mathrm{Hf}_{0.5} \mathrm{Ti}_{0.5}\right) \mathrm{B}_{2}$ and $\left(\mathrm{Zr}_{0.5} \mathrm{Ti}_{0.5}\right) \mathrm{B}_{2}$ differed significantly from the values reported for the nominal phases $\left(\left(\mathrm{Hf}_{0.5} \mathrm{Ti}_{0.5}\right) \mathrm{B}_{2}: \mathrm{a}=3.085 \AA ; \mathrm{c}=3.368 \AA ;\left(\mathrm{Zr}_{0.5} \mathrm{Ti}_{0.5}\right) \mathrm{B}_{2}:\right.$ a: $3.098 \AA$; $c=3.390 \AA$ ) [34]. This evidence suggests that the latter two phases may have contained a variable amount of the other elements of the mixture, particularly Mo, which were responsible for the observed discrepancies in cell parameters.

The obtained SHS products were also examined by SEM and EDS before being mechanically treated. The corresponding results are shown in Figure 2. From the elemental maps, it was apparent that, in agreement with the XRD analysis, the five metal elements were not homogeneously distributed across each grain. Nevertheless, a reasonably good level of mixing was achieved for all three systems after SHS, which was extremely impor- 
tant, as discussed later, to promote the formation of a single-phase product during the sintering step.
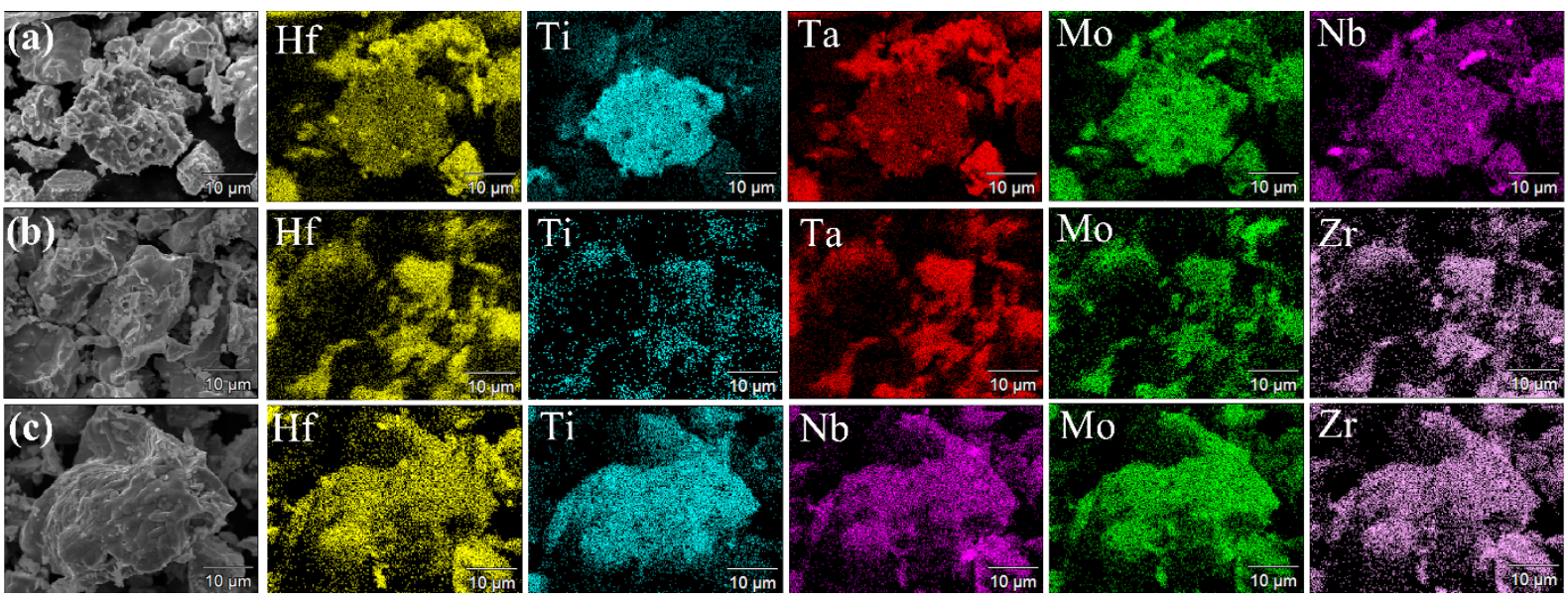

Figure 2. SEM micrographs and corresponding EDS elemental maps of (a) HEB_a, (b) HEB_b, and (c) HEB_c powders prepared by SHS.

The ball milled powders to be consolidated by SPS were also characterized in terms of particle size. The resulting data measured by laser light scattering analysis are summarized in Table 3. The three sets of powders displayed similar particle size, with an average diameter $\left(\mathrm{d}_{\mathrm{av}}\right)$ in the range of 2.7-3.7 $\mu \mathrm{m}$. Slightly finer powders were observed for the case of the HEB_b system.

Table 3. Particle size characteristics, as determined by laser scattering analysis, of HEB powders obtained by SHS after the ball milling treatment $(\mathrm{CR}=2,1 \mathrm{~h})$.

\begin{tabular}{ccccc}
\hline System & $\mathbf{d}_{\mathbf{1 0}}(\mu \mathrm{m})$ & $\mathbf{d}_{\mathbf{5 0}}(\mu \mathrm{m})$ & $\mathbf{d}_{\mathbf{9 0}}(\mu \mathrm{m})$ & $\mathbf{d}_{\mathbf{a v}}(\mu \mathrm{m})$ \\
\hline HEB_a & 0.16 & 1.13 & 11.69 & 3.69 \\
\hline HEB_b & 0.25 & 1.29 & 8.49 & 2.93 \\
\hline HEB_c & 0.19 & 1.29 & 10.84 & 3.46 \\
\hline
\end{tabular}

\subsection{Spark Plasma Sintering and Structural Characterization of Dense Products}

The three groups of SHS powders described above (Table 3) were sintered by SPS under the same conditions $\left(1950{ }^{\circ} \mathrm{C} / 20 \mathrm{~min} / 20 \mathrm{MPa}\right)$. It should be noted that the latter ones as well as the graphite amount used as additive were selected on the basis of systematic studies performed in previous works $[8,13]$. In this regard, it is important to highlight the beneficial effect produced by the introduction $1 \mathrm{wt} \%$ graphite to the SHS powders for the removal of oxide impurities and densification improvement of SPS products [8]. This fact is clearly confirmed by this study. Indeed, as reported in Figure 3, the XRD patterns of bulk samples indicated that single-phase ceramics were formed after SPS with hardly detectable oxide contaminants or other secondary products for the three HEB systems. Therefore, it can be stated that the multiphase SHS powders were successfully converted into the desired $\left(\mathrm{Hf}_{0.2} \mathrm{Nb}_{0.2} \mathrm{Ta}_{0.2} \mathrm{Mo}_{0.2} \mathrm{Ti}_{0.2}\right) \mathrm{B}_{2},\left(\mathrm{Hf}_{0.2} \mathrm{Zr}_{0.2} \mathrm{Ta}_{0.2} \mathrm{Mo}_{0.2} \mathrm{Ti}_{0.2}\right) \mathrm{B}_{2}$, and $\left(\mathrm{Hf}_{0.2} \mathrm{Zr}_{0.2} \mathrm{Nb}_{0.2} \mathrm{Mo}_{0.2} \mathrm{Ti}_{0.2}\right) \mathrm{B}_{2}$ by SPS. In this context, the latter process should be, then, more properly considered as reactive sintering instead of a "simple" powder consolidation step. As mentioned in the Introduction, the direct synthesis and the concurrent densification starting from elemental powder resulted in multiphase products [13]. Thus, the SHS step was strictly required to properly activate the powders and finally obtain a monophasic ceramic by SPS. The final densities of the obtained sintered samples are listed in Table 4 along with the lattice parameters evaluated by Rietveld analysis. For comparison, the related values reported in the literature for the same systems are also indicated in Table 4 . Rietveld 
analysis also provided an estimate of the average crystallite size of the high entropy ceramic phases, namely 811,693 , and $1532 \AA$ for the cases of $\left(\mathrm{Hf}_{0.2} \mathrm{Nb}_{0.2} \mathrm{Ta}_{0.2} \mathrm{Mo}_{0.2} \mathrm{Ti}_{0.2}\right) \mathrm{B}_{2}$, $\left(\mathrm{Hf}_{0.2} \mathrm{Zr}_{0.2} \mathrm{Ta}_{0.2} \mathrm{Mo}_{0.2} \mathrm{Ti}_{0.2}\right) \mathrm{B}_{2}$, and $\left(\mathrm{Hf}_{0.2} \mathrm{Zr}_{0.2} \mathrm{Nb}_{0.2} \mathrm{Mo}_{0.2} \mathrm{Ti}_{0.2}\right) \mathrm{B}_{2}$, respectively. It is important to note that the HE system which displayed relatively larger crystallite size was HEB_c, i.e., the one free of Ta. It is then presumable that the presence of the latter highly refractory element could play a role in making relatively finer microstructrures. Three SEM micrographs and the corresponding EDS elemental maps of SPS products are shown in Figure 4. The obtainment of nearly full dense samples was confirmed, particularly when considering the HEB_c product. In this regard, the residual porosity values estimated by image analysis for HEB_a, HEB_b, and HEB_c specimens were $1.2 \pm 0.2,2.2 \pm 0.2$, and $0.3 \pm 0.1 \mathrm{vol} . \%$, respectively. In addition to the high densification level achieved by SPS, it is also important to evidence the satisfying elemental distribution observed across the sample. Additionally, in this case, the HEB_c ceramic was characterized by the best compositional homogeneity.

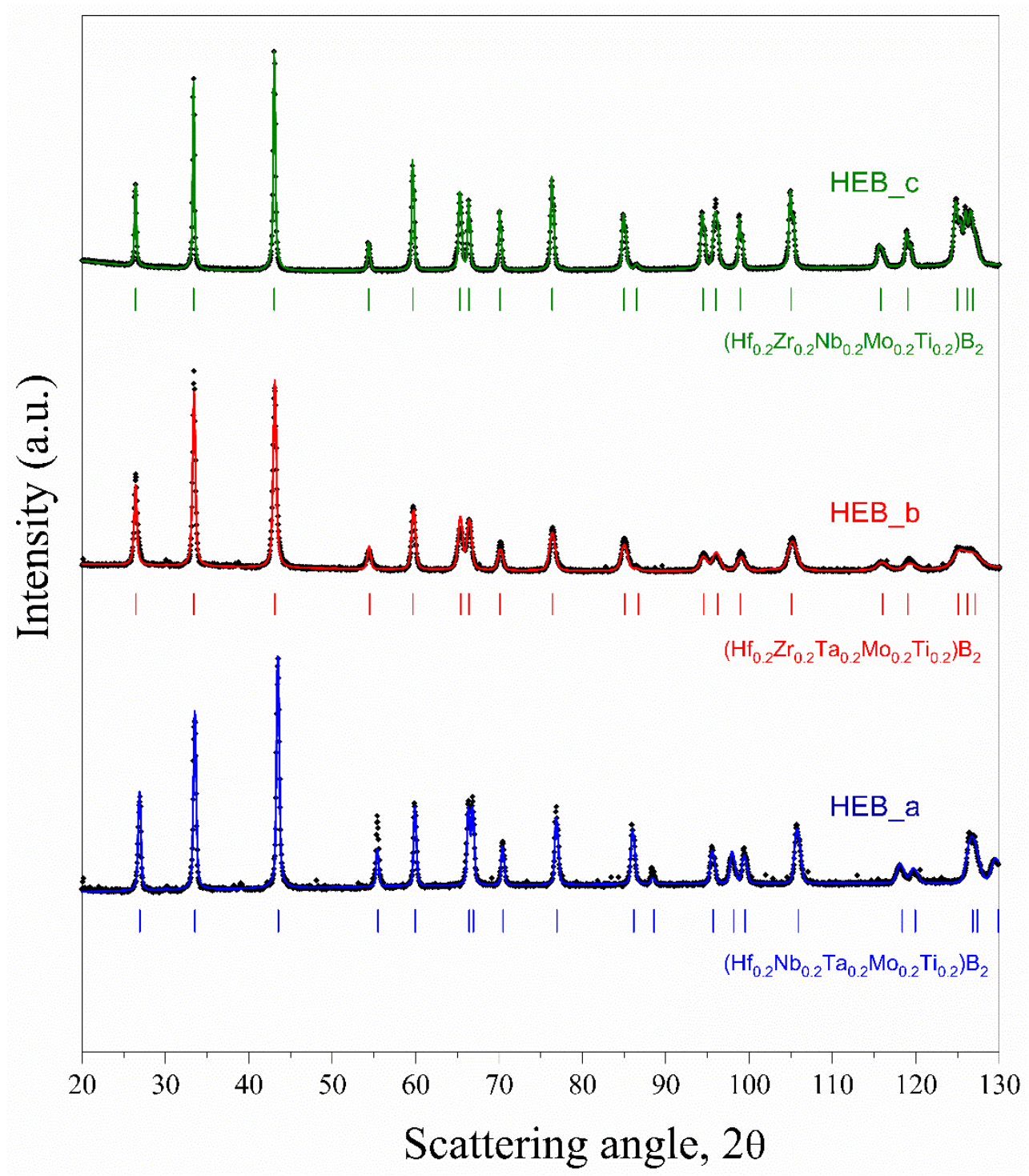

Figure 3. XRD pattern and related Rietveld refinement of dense HE products obtained by SPS. 
Table 4. Density and lattice parameters of the three HEB products obtained by SPS in this work. The corresponding values reported in the literature for the same systems are also included.

\begin{tabular}{|c|c|c|c|c|}
\hline System & $\begin{array}{c}\rho_{\mathrm{t}} \\
\left(\mathrm{g} / \mathrm{cm}^{3}\right)\end{array}$ & $\begin{array}{c}\rho \\
(\%)\end{array}$ & $\begin{array}{l}\text { Lattice Parameters } \\
\quad \mathbf{a}(\dot{\mathrm{A}}), \mathrm{c}(\dot{\mathrm{A}})\end{array}$ & Reference \\
\hline \multirow{4}{*}{ HEB_a } & 8.67 & $97.4 \pm 0.3$ & $3.087,3.316$ & This work \\
\hline & 8.67 & 92.2 & $3.082,3.279$ & [1] \\
\hline & 8.61 & 95.0 & $3.082,3.307$ & [6] \\
\hline & 8.61 & 98.5 & $3.082,3.281$ & [7] \\
\hline \multirow{3}{*}{ HEB_b } & 8.52 & $96.5 \pm 0.7$ & $3.092,3.368$ & This work \\
\hline & 8.52 & 92.4 & $3.080,3.316$ & [1] \\
\hline & 8.37 & 99.9 & $3.092,3.366$ & [10] \\
\hline \multirow{3}{*}{ HEB_c } & 7.37 & $98.2 \pm 0.9$ & $3.099,3.374$ & This work \\
\hline & 7.37 & 92.3 & $3.092,3.345$ & [1] \\
\hline & 7.29 & 97.7 & $3.093,3.353$ & [6] \\
\hline
\end{tabular}
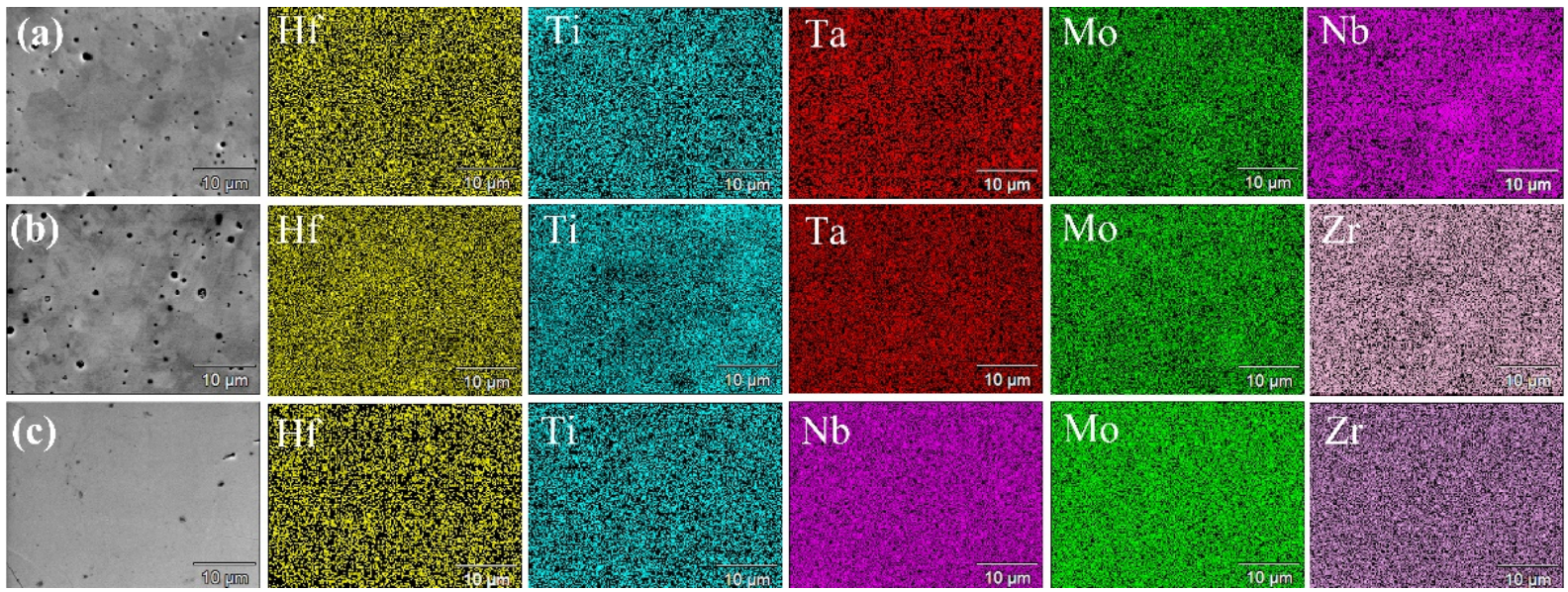

Figure 4. Cross sectional SEM micrographs and related EDS elemental maps of (a) HEB_a, (b) HEB_b, and (c) HEB_c products obtained by SPS from SHS powder.

\subsection{Mechanical Properties of Sintered Samples}

The results of the mechanical properties in terms of Vickers hardness, Young's modulus, and fracture toughness are summarized in Table 5 for the HEB_a, HEB_b, and HEB_c sintered samples along with the available literature data.

The highest elastic modulus was achieved for the HEB_a system. Even though no such data are reported in literature for this system, the values determined for the hardness were consistent with the ones reported previously [7]. Moreover, values of fracture toughness were comparable with the one reported in the same work, even if the HEB_a samples prepared in this work displayed slightly higher values.

On the other hand, HEB_b had a lower elastic modulus compared to HEB_a but had a remarkably high value of hardness, being also the hardest of the three systems.

HEB_c, which corresponded to the greatest relative density (see Table 4), showed lower values of hardness and elastic modulus compared to HEB_a and HEB_b; however, this system displayed the best fracture toughness. The very good $\mathrm{K}_{\mathrm{IC}}$ can be ascribed to the higher degree of densification achieved. 
Table 5. Mechanical properties of the three HEB products obtained by SPS in this work. The corresponding values reported in the literature for the same systems are also included. E\&C: Evans and Charles; L\&F: Lawn and Fuller; E\&W: Evans and Wilshaw; L: Lankford. n.r.: not reported.

\begin{tabular}{|c|c|c|c|c|c|}
\hline System & $\begin{array}{c}\text { Conditions } \\
\text { (Load, Loading Time, } \\
\text { Loading/Unloading Rate) }\end{array}$ & $\begin{array}{c}\mathrm{Hv} \\
(\mathrm{GPa})\end{array}$ & $\begin{array}{l}\text { Young's Modulus } \\
\text { (GPa) }\end{array}$ & $\begin{array}{c}\mathrm{K}_{\mathrm{IC}} \\
\text { (MPa m}^{1 / 2} \text { ) } \\
\text { Method }\end{array}$ & Reference \\
\hline \multirow{6}{*}{ HEB_a } & $0.25 \mathrm{~N}, 15 \mathrm{~s}, 0.5 \mathrm{~N} / \mathrm{min}$ & $28.1 \pm 3.5$ & $538.5 \pm 49.9$ & - & \multirow[b]{3}{*}{ This work } \\
\hline & $0.5 \mathrm{~N}, 15 \mathrm{~s}, 1 \mathrm{~N} / \mathrm{min}$ & $27.8 \pm 2.2$ & $546.3 \pm 20.1$ & - & \\
\hline & $1 \mathrm{~N}, 15 \mathrm{~s}, 2 \mathrm{~N} / \mathrm{min}$ & - & - & $\begin{array}{c}7.06(\mathrm{E} \& \mathrm{C}) \\
4.41(\mathrm{~L} \& \mathrm{~F}) \\
4.49(\mathrm{E} \& W) \\
10.31(\mathrm{~L})\end{array}$ & \\
\hline & $1.96 \mathrm{~N}, 15$ s, n.r. & $22.5 \pm 1.7$ & n.r. & n.r. & [1] \\
\hline & $1.96 \mathrm{~N}, 15$ s, n.r. & $25.9 \pm 1.1$ & n.r. & n.r. & [6] \\
\hline & $1.96 \mathrm{~N}, 15 \mathrm{~s}, \mathrm{n} . \mathrm{r}$. & $27.0 \pm 0.4$ & n.r. & $4.47 \pm 0.40(\mathrm{E} \& \mathrm{C})$ & [7] \\
\hline \multirow{5}{*}{ HEB_b } & $0.25 \mathrm{~N}, 15 \mathrm{~s}, 0.5 \mathrm{~N} / \mathrm{min}$ & $28.08 \pm 1.6$ & $498.1 \pm 28.3$ & - & \multirow{2}{*}{ This work } \\
\hline & $0.5 \mathrm{~N}, 15 \mathrm{~s}, 1 \mathrm{~N} / \mathrm{min}$ & $29.7 \pm 1.9$ & $514.8 \pm 41.5$ & - & \\
\hline & $1 \mathrm{~N}, 15 \mathrm{~s}, 2 \mathrm{~N} / \mathrm{min}$ & - & - & $\begin{array}{c}4.31(\mathrm{E} \& \mathrm{C}) \\
2.69(\mathrm{~L} \& \mathrm{~F}) \\
3.82(\mathrm{E} \& W) \\
5.84(\mathrm{~L})\end{array}$ & \\
\hline & $1.96 \mathrm{~N}, 15$ s, n.r. & $19.1 \pm 1.8$ & n.r. & n.r. & [1] \\
\hline & $1.96 \mathrm{~N}, 15$ s, n.r. & $24.9 \pm 1.0$ & n.r. & n.r. & [10] \\
\hline \multirow{5}{*}{ HEB_c } & $0.25 \mathrm{~N}, 15 \mathrm{~s}, 0.5 \mathrm{~N} / \mathrm{min}$ & $25.1 \pm 3.8$ & $404.5 \pm 57.8$ & - & \multirow[b]{2}{*}{ This work } \\
\hline & $1 \mathrm{~N}, 15 \mathrm{~s}, 2 \mathrm{~N} / \mathrm{min}$ & - & - & $\begin{array}{c}8.84(\mathrm{E} \& \mathrm{C}) \\
5.53(\mathrm{~L} \& \mathrm{~F}) \\
5.12(\mathrm{E} \& W) \\
12.0(\mathrm{~L})\end{array}$ & \\
\hline & $1.96 \mathrm{~N}, 15 \mathrm{~s}, \mathrm{n} . \mathrm{r}$. & $21.9 \pm 1.7$ & n.r. & - & [1] \\
\hline & $1.96 \mathrm{~N}, 15 \mathrm{~s}$, n.r. & $26.3 \pm 0.7$ & n.r. & - & [6] \\
\hline & $1.96 \mathrm{~N}, 15$ s, n.r. & $26.3 \pm 1.8$ & n.r. & $3.64 \pm 0.36(\mathrm{E} \& C)$ & [7] \\
\hline
\end{tabular}

Some additional considerations can be made regarding the generally lower mechanical properties displayed by the $\left(\mathrm{Hf}_{0.2} \mathrm{Zr}_{0.2} \mathrm{Nb}_{0.2} \mathrm{Mo}_{0.2} \mathrm{Ti}_{0.2}\right) \mathrm{B}_{2}$ product, in spite of the fact that a relatively higher densification level was achieved compared to the other two HE ceramics obtained in this work. First, it should be noted that both HEB_a and HEB_b contained tantalum, while such an element was not present in HEB_c. Fully dense Ta-based UHTCs are generally quite difficult to obtain, thus the introduction of suitable sintering additives is needed to achieve such a target. For instance, the use of the SHS-SPS approach to produce bulk $\mathrm{TaB}_{2}$ led to poor relative density, i.e., $93.9 \pm 0.3 \%$ [21]. On the other hand, highly dense products $(98.5 \pm 0.3 \%$ ) were obtained under the same operating conditions when processing $\mathrm{ZrB}_{2}$. In contrast, the corresponding measured hardness values were $17.5\left(\mathrm{TaB}_{2}\right)$ and $11.0\left(\mathrm{ZrB}_{2}\right) \mathrm{GPa}$, respectively. Product microstructure was also relatively finer in the first case, with average grain sizes of 7 and $20 \mu \mathrm{m}$, respectively [21]. All these outcomes are consistent with the results obtained in this work to testify that the presence of Ta in the HE borides makes the obtainment of fully dense products more difficult, whereas the corresponding ceramics exhibit a finer microstructure and improved mechanical properties.

\section{Conclusions}

In this work, three quinary HE diborides were successfully obtained in dense form by SPS using powders preliminarily prepared by SHS from elemental precursors. Detailed XRD analysis coupled with the Rietveld analytical procedure evidenced that reactants were only partially converted by SHS into the desired HE phase, while other individual $\left(\mathrm{NbB}_{2}\right.$, etc. $)$ and binary $\left(\left(\mathrm{Hf}_{0.5} \mathrm{Ti}_{0.5}\right) \mathrm{B}_{2},\left(\mathrm{Zr}_{0.5} \mathrm{Ti}_{0.5}\right) \mathrm{B}_{2}\right.$, etc.) diborides were also found in the 
synthesized product. However, secondary phases were completely transformed into the nominal HE ceramics during the subsequent SPS stage conducted for $20 \mathrm{~min}$ at $1950{ }^{\circ} \mathrm{C}$ and $20 \mathrm{MPa}$. The introduction of $1 \mathrm{wt} . \%$ of graphite to the SHS powder before their consolidation was beneficial to improve the resulting product density and purity. The estimated average crystallite sizes for $\left(\mathrm{Hf}_{0.2} \mathrm{Nb}_{0.2} \mathrm{Ta}_{0.2} \mathrm{Mo}_{0.2} \mathrm{Ti}_{0.2}\right) \mathrm{B}_{2},\left(\mathrm{Hf}_{0.2} \mathrm{Zr}_{0.2} \mathrm{Ta}_{0.2} \mathrm{Mo}_{0.2} \mathrm{Ti}_{0.2}\right) \mathrm{B}_{2}$, and $\left(\mathrm{Hf}_{0.2} \mathrm{Zr}_{0.2} \mathrm{Nb}_{0.2} \mathrm{Mo}_{0.2} \mathrm{Ti}_{0.2}\right) \mathrm{B}_{2}$ in the sintered ceramics were about 800,700 , and $1500 \AA$, respectively. Highly dense and homogeneous ceramics were correspondingly obtained, particularly when considering $\left(\mathrm{Hf}_{0.2} \mathrm{Zr}_{0.2} \mathrm{Nb}_{0.2} \mathrm{Mo}_{0.2} \mathrm{Ti}_{0.2}\right) \mathrm{B}_{2}$. The Vickers hardnesses of 28.1 and $28.08 \mathrm{GPa}$ measured for the $\left(\mathrm{Hf}_{0.2} \mathrm{Nb}_{0.2} \mathrm{Ta}_{0.2} \mathrm{Mo}_{0.2} \mathrm{Ti}_{0.2}\right) \mathrm{B}_{2}$, and $\left(\mathrm{Hf}_{0.2} \mathrm{Zr}_{0.2} \mathrm{Ta}_{0.2} \mathrm{Mo}_{0.2} \mathrm{Ti}_{0.2}\right) \mathrm{B}_{2}$ materials, respectively, were superior with respect to value obtained for the third ceramic (25.1 GPa). This holds also true when considering the Young's moduli, i.e., 538.5, 498.1, and $404.5 \mathrm{GPa}$, respectively. The presence of the highly refractory Ta element in the first two systems likely played a role in this regard, albeit the corresponding products displayed relatively higher residual average porosities, i.e., $1.2,2.2$, and 0.3 vol. $\%$, respectively. Although only a few mechanical properties data have been reported in the literature for this emerging class of ceramics, the comparison with them, when available, evidenced that the three HE ceramics prepared in this work display similar and, in some cases, slightly better $\mathrm{Hv}$ and fracture toughness values.

In summary, it is possible to conclude that single phase HE diborides characterized by high density and promising mechanical properties could be attained under rather advantageous processing conditions by combining the SHS and the SPS techniques. An important role is played by the use of combustion synthesis route, which can provide very shortly highly activated powders, where the elemental constituents are finely distributed to suitably promote the formation of the HE phases during the consolidation (and reactive) SPS step.

Author Contributions: Conceptualization, R.O., and G.C.; methodology, S.B., A.I., V.C., and M.M.; investigation, S.B., A.I., and V.C.; writing-original draft preparation, R.O., V.C., S.G., and S.B.; writing-review and editing, S.B., R.O., V.C., S.G., G.C. All authors have read and agreed to the published version of the manuscript.

Funding: This research was funded by Regione Autonoma della Sardegna (Italy)-Fondo di Sviluppo e Coesione (FSC) 2014-2020, ARCHIMEDES project (Cod. RAS: RASSR88309, Cod. CUP: F76C18000980002).

Institutional Review Board Statement: Not applicable.

Informed Consent Statement: Not applicable.

Data Availability Statement: Data are contained within the article.

Acknowledgments: Two of the authors (S.B. and M.M.) performed their activity in the framework of the International $\mathrm{PhD}$ in Innovation Sciences and Technologies at the University of Cagliari, Italy. One of us (G.C.) acknowledges the results obtained in this manuscript as quite important for the "Ithermal" and "Generazione E" projects, sponsored by Sardegna Ricerche, Italy (Cod. CUP: F21I18000130006) and by the Italian Ministry of Education, University and Research, Italy (Cod. CUP: B96G18000560005), respectively. Thanks are due to Roberta Licheri (University of Cagliari) for her useful contribution as well as Daniele Lai and Gianluca Marongiu (University of Cagliari) for their technical assistance. The authors, S.G. and A.I., acknowledge the support of the CeSAR UNISS, Centro Servizi di Ateneo per la Ricerca of the University of Sassari, for making available XRD apparatus to carry out materials characterization.

Conflicts of Interest: The authors declare no conflict of interest. The funders had no role in the design of the study; in the collection, analyses, or interpretation of data; in the writing of the manuscript, or in the decision to publish the results. 


\section{References}

1. Gild, J.; Zhang, Y.; Harrington, T.; Jiang, S.; Hu, T.; Quinn, M.C.; Mellor, W.M.; Zhou, N.; Vecchio, K.; Luo, J. High-Entropy Metal Diborides: A New Class of High-Entropy Materials and a New Type of Ultrahigh Temperature Ceramics. Sci. Rep. 2016, 6, 37946. [CrossRef]

2. Tsai, M.H.; Yeh, J.W. High-Entropy Alloys: A Critical Review. Mater. Res. Lett. 2014, 2, 107-123. [CrossRef]

3. Gild, J.; Kaufmann, K.; Vecchio, K.; Luo, J. Reactive Flash Spark Plasma Sintering of High-Entropy Ultrahigh Temperature Ceramics. Scr. Mater. 2019, 170, 106-110. [CrossRef]

4. Gu, J.F.; Zou, J.; Sun, S.K.; Wang, H.; Yu, S.Y.; Zhang, J.; Wang, W.; Fu, Z. Dense And Pure High-Entropy Metal Diboride Ceramics Sintered from Self-Synthesized Powders via Boro/Carbothermal Reduction Approach. Sci. China Mater. 2019, 62, 1898-1909. [CrossRef]

5. Tallarita, G.; Licheri, R.; Garroni, S.; Orrù, R.; Cao, G. Novel Processing Route for the Fabrication of Bulk High-Entropy Metal Diborides. Scr. Mater. 2019, 158, 100-104. [CrossRef]

6. Zhang, Y.; Guo, W.M.; Jiang, Z.B.; Zhu, Q.Q.; Sun, S.K.; You, Y.; Plucknett, K.; Lin, H.T. Dense High-Entropy Boride Ceramics with Ultra-High Hardness. Scr. Mater. 2019, 164, 135-139. [CrossRef]

7. Zhang, Y.; Jiang, Z.B.; Sun, S.K.; Guo, W.M.; Chen, Q.S.; Qiu, J.X.; Plucknett, K.; Lin, H.T. Microstructure and Mechanical Properties of High-Entropy Borides Derived from Boro/Carbothermal Reduction. J. Eur. Ceram. Soc. 2019, 39, 3920-3924. [CrossRef]

8. Barbarossa, S.; Orrù, R.; Garroni, S.; Licheri, R.; Cao, G. Ultra High Temperature High-Entropy Borides: Effect of Graphite Addition on Oxides Removal and Densification Behavior. Ceram. Int. 2021, 47, 6220-6231. [CrossRef]

9. Feng, L.; Fahrenholtz, W.G.; Hilmas, G.E. Processing of Dense High-Entropy Boride Ceramics. J. Eur. Ceram. Soc. 2020, 40, 3815-3823. [CrossRef]

10. Gild, J.; Wright, A.; Quiambao-Tomko, K.; Qin, M.; Tomko, J.A.; Md Shafkat bin, H.; Braun, J.L.; Bloomfield, B.; Martinez, D.; Harrington, T.; et al. Thermal Conductivity and Hardness of Three Single-Phase High-Entropy Metal Diborides Fabricated by Borocarbothermal Reduction and Spark Plasma Sintering. Ceram. Int. 2020, 46, 6906-6913. [CrossRef]

11. Qin, M.; Gild, J.; Wang, H.; Harrington, T.; Vecchio, K.S.; Luo, J. Dissolving and Stabilizing Soft WB2 and MoB2 Phases into High-Entropy Borides Via Boron-Metals Reactive Sintering to Attain Higher Hardness. J. Eur. Ceram. Soc. 2020, 40, 4348-4353. [CrossRef]

12. Qin, M.; Gild, J.; Hu, C.; Wang, H.; Hoque, M.S.B.; Braun, J.L.; Harrington, T.J.; Hopkins, P.E.; Vecchio, K.S.; Luo, J. Dual-Phase High-Entropy Ultra-High Temperature Ceramics. J. Eur. Ceram. Soc. 2020, 40, 5037-5050. [CrossRef]

13. Tallarita, G.; Licheri, R.; Garroni, S.; Barbarossa, S.; Orrù, R.; Cao, G. High-Entropy Transition Metal Diborides by Reactive and Non-Reactive Spark Plasma Sintering: A Comparative Investigation. J. Eur. Ceram. Soc. 2020, 40, 942-952. [CrossRef]

14. Zhang, Y.; Sun, S.K.; Zhang, W.; You, Y.; Guo, W.M.; Chen, Z.W.; Yuan, J.H.; Lin, H.T. Improved Densification and Hardness of High Entropy Diboride Ceramics from Fine Powders Synthesized via Borothermal Reduction Process. Ceram. Int. 2020, 46, 14299-14303. [CrossRef]

15. Feng, L.; Fahrenholtz, W.G.; Hilmas, G.E.; Monteverde, F. Effect of Nb Content on the Phase Composition, Densification, Microstructure, and Mechanical Properties of High-Entropy Boride Ceramics. J. Eur. Ceram. Soc. 2021, 41, 92-100. [CrossRef]

16. Zhang, Y.; Sun, S.K.; Guo, W.M.; Zhang, W.; Xu, L.; Yuan, J.H.; Guan, D.K.; Wang, D.W.; You, Y.; Lin, H.T. Fabrication of Textured (Hf0.2Zr0.2Ta0.2Cr0.2Ti0.2)B2 High-Entropy Ceramics. J. Eur. Ceram. Soc. 2021, 41, 1015-1019.

17. Orrù, R.; Licheri, R.; Locci, A.M.; Cincotti, A.; Cao, G. Consolidation/Synthesis of Materials by Electric Current Activated/Assisted Sintering. Mater. Sci. Eng. R 2009, 63, 127-287. [CrossRef]

18. Mishra, K.; Das, S.; Pathak, L.C. Defect Structures in Zirconium Diboride Powder Prepared by Self-Propagating High-Temperature Synthesis, Mater. Sci. Eng. A 2004, 364, 249-255. [CrossRef]

19. Licheri, R.; Orrù, R.; Musa, C.; Cao, G. Combination of SHS and SPS Techniques for Fabrication of Fully Dense ZrB2-ZrC-SiC Composites. Mater. Lett. 2008, 62, 432-435. [CrossRef]

20. Musa, C.; Orrù, R.; Sciti, D.; Silvestroni, L.; Cao, G. Synthesis, Consolidation and Characterization of Monolithic and SiC Whiskers Reinforced Hfb2 Ceramics. J. Eur. Ceram. Soc. 2013, 33, 603-614. [CrossRef]

21. Licheri, R.; Musa, C.; Orrù, R.; Cao, G.; Sciti, D.; Silvestroni, L. Bulk Monolithic Zirconium and Tantalum Diborides by Reactive and Non-Reactive Spark Plasma Sintering. J. Alloy Compd. 2016, 663, 351-359. [CrossRef]

22. İpekçi, M.; Acar, S.; Elmadağl1, M.; Hennicke, J.; Balc1, Ö.; Somer, M. Production of TiB2 by SHS and HCl Leaching at Different Temperatures: Characterization and Investigation of Sintering Behavior by SPS. Ceram. Int. 2017, 43, 2039-2045. [CrossRef]

23. Sani, E.; Meucci, M.; Mercatelli, L.; Balbo, A.; Musa, C.; Licheri, R.; Orrù, R.; Cao, G. Titanium Diboride Ceramics for Solar Thermal Absorbers. Sol. Energy Mater. Sol. Cells 2017, 169, 313-319. [CrossRef]

24. Licheri, R.; Musa, C.; Locci, A.M.; Montinaro, S.; Orrù, R.; Cao, G.; Silvestroni, L.; Mercatelli, L.; Sani, E. Ultra-High Temperature Porous Graded Ceramics for Solar Energy Applications. J. Eur. Ceram. Soc. 2019, 39, 72-78. [CrossRef]

25. Kurbatkina, V.V.; Patsera, E.I.; Smirnov, D.V.; Levashov, E.A.; Vorotilo, S.; Timofeev, A.N. Part 2. Structure, Mechanical and Thermophysical Properties Of Consolidated Ceramics Based on (Hf,Ta)B2. Ceram. Int. 2019, 45, 4076-4083.

26. Cincotti, A.; Licheri, R.; Locci, A.M.; Orrù, R.; Cao, G. A Review on Combustion Synthesis of Novel Materials: Recent Experimental and Modeling Results. J. Chem. Technol. Biotechnol. 2003, 78, 122-127. [CrossRef] 
27. Lutterotti, L.; Ceccato, R.; Dal Maschio, R.; Pagani, E. Quantitative Analysis of Silicate Glass in Ceramic Materials by the Rietveld method. Mater. Sci. Forum 1998, 87, 278-281. [CrossRef]

28. Schneider, C.A.; Rasband, W.S.; Eliceiri, K.W. NIH Image to ImageJ: 25 Years of Image Analysis. Nat. Methods 2012, 9, 671-675. [CrossRef]

29. Oliver, W.; Pharr, G. An Improved Technique for Determining Hardness and Elastic Modulus Using Load and Displacement Sensing Indentation Experiments. J. Mater. Res. 1992, 7, 1564-1583. [CrossRef]

30. Ponton, C.B.; Rawlings, R.D. Vickers Indentation Fracture Toughness Test. Part 1: Review of Literature and Formulation of Standardised Indentation Toughness Equations. Mater. Sci. Technol. 1989, 5, 865-872.

31. Ponton, C.B.; Rawlings, R.D. Vickers Indentation Fracture Tough-Ness Test. Part 2: Application and Critical Evaluation of Standardised Indentation Toughness Equations. Mater. Sci. Technol. 1989, 5, 961-976.

32. Barin, I. Thermochemical Data of Pure Substances; VHC: Weinheim, Germany, 1989.

33. Norton, J.T.; Blumenthal, H.; Sindeband, S.J. Structures of Diborides of Titanium, Zirconium, Columbium, Tantalum and Vanadium. JOM 1949, 185, 749-751. [CrossRef]

34. Glaser, F.W.; Post, B.; Moskowitz, D. Transition Metal Diborides. Acta Met. 1954, 2, $20-25$. 